\title{
Intimate partner violence among Portuguese speaking immigrant adult women in Canada
}

\section{Violência por parceiro íntimo entre mulheres imigrantes que falam o português no Canadá Violencia por pareja íntima entre mujeres inmigrantes que hablan portugués en Canadá}

Rafaella Queiroga Souto ${ }^{1}$, Sepali Guruge ${ }^{2}$, Miriam Aparecida Barbosa Merighi ${ }^{3}$, Maria Cristina Pinto de Jesus ${ }^{3}$, Shaindel Egit' ${ }^{2}$ Linda Knowles ${ }^{4}$

How to cite this article:

Souto RQ, Guruge S, Merighi MAB, Jesus MCP Egit S, Knowles L. Intimate partner violence among speaking immigrant adult Portuguese women in Canada. Rev Esc Enferm USP. 2016;50(6):905-912. DOI: http://dx.doi.org/10.1590/S0080-623420160000700005

${ }^{1}$ Universidade Federal de Pernambuco, Departamento de Enfermagem, Recife, PB, Brazil.

${ }^{2}$ Ryerson University, Department of Nursing, Toronto, Ontario, Canada.

${ }^{3}$ Universidade de São Paulo, Escola de Enfermagem, Departamento de

Enfermagem Materno Infantil e

Psiquiátrica, São Paulo, SP, Brazil.

${ }^{4}$ Knowles Consulting, Toronto, Ontario, Canada.

\section{ABSTRACT}

Objective: This study was conducted to understand the experiences of intimate partner violence among women from Portuguese-speaking countries living in the Greater Toronto Area. Method: A social phenomenological study was conducted with ten Portuguesespeaking women who had experienced intimate partner violence who were selected by community centre leaders. The interviews were transcribed, translated and analysed by categories. Results: The consequences of violence included health problems, effects on children, and negative feelings among the victims. Factors preventing the women from leaving abusive partners included religious beliefs, challenging daily jobs, and the need to take care of their husband. Factors that encouraged them to leave included getting support and calling the police. Some women expressed hope for the future either with their husband. Others, desired divorce or revenge. Their plans to rebuild their lives without their husband included being happy, learning English, and being financially stable. Conclusion: Using these findings can implicate in the improvement of care for these women.

\section{DESCRIPTORS}

Domestic Violence; Emigrants and Immigrants; Intimate Partner Violence; Spouse Abuse; Forensic Nursing. 


\section{INTRODUCTION}

Intimate partner violence (IPV) has been identified as an important public social and health problem that affects people everywhere ${ }^{(1-2)}$.

According to Thomas et al, 1.5 to 5.3 million women of women per year report being physically and/or sexually victimized by their male partners at some time in their life ${ }^{(2)}$. In the United States, the lifetime prevalence of physical and sexual IPV ranges from $25-50 \%{ }^{(3)}$. The mean prevalence rate of IPV in North America is 21\% (IC: 16-26\%), in Central Europe it is 28\% (IC: $23-33 \%$ ), and in Latin America it is 24\% (IC: $13-34 \%)^{(4)}$. IPV can occur in marital or dating relationships, and in same-sex or opposite-sex relationships. It can also continue after a relationship has ended ${ }^{(3)}$. Women comprise more than $70 \%$ of the victims of IPV ${ }^{(5)}$ and most women have experienced violence. Evidence suggests that most women who present to emergency departments have experienced domestic abuse at some point in their lives, but that only $5 \%$ are identified by healthcare professionals ${ }^{(1)}$.

Women who are victims of IPV report more physical complaints and symptoms, particularly about cardiovascular, nervous, digestive and genitourinary systems than women with no history of IPV, and their health problems may persist after the abuse has ended ${ }^{(6)}$. Health consequences of IPV may include anxiety, anger, helplessness, hopelessness, low self-esteem, depression, excessive use of drugs or alcohol, gastrointestinal disorders, genitourinary tract, musculoskeletal disorders, permanent physical disorders or disabilities, chronic diseases (e.g., hypertension, chronic pain), and even premature death $^{(1,4,6-8)}$. In Canada, it was estimated that $\$ 6.9$ billion (CAD) is spent annually to support survivors of IPV aged 19 to $65^{(9)}$.

Scholars have studied IPV among various immigrant communities in Canada ${ }^{(10-12)}$. Over four recent studies were conducted among immigrant women livings in Canada ${ }^{(13-16)}$. Toronto has approximately 58,000 Portuguese-speaking immigrants. Of these, $51 \%$ are women. Portuguese was the third largest foreign language spoken in Toronto ${ }^{(17)}$.

Research ${ }^{(13)}$ conducted with 10 Portuguese-speaking immigrant women 60 years or older who sought social services after being abused by their partners found that their personal beliefs, cultural issues and their legal situation as an immigrant in Canada has a dual potential: a restrictive and an enabling one. Sometimes, they keep their relationships because they are illegal immigrants and/or they believe that their marriage cannot be ended. A study ${ }^{(14)}$ conducted with 188 South Asian immigrants women in Canada, to assess the prevalence of IPV, found that 1 in 5 women has been a victim of IPV in the past year, and the single women were more likely to experience violence than married women. This prevalence is close to the general prevalence of IPV known in Canada. Another study ${ }^{(15)}$ conducted in Canada with a South Asian immigrant focus on the concept of IPV found that the maen's and women's views of the concept of IPV is similar. However, women related men's violent acts more as a cultural behavior than men did. A study ${ }^{(16)}$ conducted with 12 Portuguese speaking Latin American women in
Toronto who had experienced some form of IPV in their adult lives, examined the perceived relationship between IPV and depression and found that the participants perceived a powerful connection between IPV and depression. They believe that childhood abuse, war traumas and migration can make this association stronger.

Since it is an international issue that affects mainly women everywhere, and causes irreversible social and health consequences to the victims and their families; this subject needs to be researched and shared to increase the understanding of this phenomenon and to use the information generated to improve care for the victims. In this context, nurses (the professionals mostly involved with the care) may use this knowledge to better assist their patients, organize their services and educate other professionals and students around how to handle this topic. Nurses have an important role in identifying IPV when victims search for care in health care settings $\mathrm{s}^{(1)}$.

It is important to also understand in-depth the women's experiences of responses to IPV. The main research question was: What are the experiences of IPV among Portuguesespeaking women in Toronto, Canada? The sub-questions were: 1) What is daily life like for women who have experienced IPV in Toronto? 2) How do the women respond to the violent situation? 3) What are their needs, expectations, and goals in dealing with IPV?

\section{METHOD}

This study was approved by the Research Ethics Board (REB) at Ryerson University in June 2013 (REB number = 2013-160). The Principal Investigator (PI) approached the management team at a Portuguese-speaking community centre in Toronto to help recruit study participants. This community centre is an official federally-recognized charity that helps everyone in the neighbourhood - from youth to seniors. It is located in the biggest Portuguese community area in Toronto.

One of the actions of this community centre is to support victims of violence. They have a women's group that meets every week to talk freely about their personal experiences. Thus, the PI explained the study to the community leaders and asked if the research team's contact information could be distributed during one of the group meetings. The interested women, then talked to the community centre's professional. This person scheduled the interview day and time. The recruitment process was conducted from August 2013 to October 2013.

Participant criteria were: women living in the Greater Toronto Area; 18-59 years old; Portuguese-speaking; immigrant i.e. (born outside Canada); current or past experience of IPV.

Participants were asked to select the time and location of their interview, to ensure they felt comfortable and safe talking about their experiences. All participants chose to be interviewed at the community centre. Participants were informed about the study, the use of a tape recorder, how confidentiality would be maintained, and their right to withdraw from the study at any time without any repercussions. 
They were also advised that some topics might be difficult to discuss, and that the PI would be required to report any possible harm to self or others, or child abuse or neglect, to the authorities. After this verbal explanation, participants were asked to read and sign a consent form.

Demographic data were collected, including age, marital status, number of children, relationships to all household members, and income that the woman provided to the household. Data collection, data analysis, and sampling of participants were conducted simultaneously. The number of participants was not predetermined.

Each interview lasted approximately 1-2 hours, was conducted in Portuguese, and was audiotaped, transcribed verbatim in Portuguese, and then translated into English. Data collection concluded when the key ideas and concepts in the interviews became repetitious. Confidentiality was maintained by: 1) assigning all participants code numbers; 2) not phoning participants; 3 ) ensuring the community centre's leaders were not aware of women's decision to participate or not in the study; 4) destroying interview tapes after the interviews were transcribed and checked for accuracy; and 5) deciding to destroy transcripts five years after the completion of the study.

At the end of interviews, participants were given an information sheet printed in English and Portuguese, including a variety of confidential and accessible counselling and referral services. They also received an honorarium to help defray the costs of travel, childcare, or grandchild care arrangements.

A total of 10 women participated in the study. Of these, six participants were from Brazil and four were from Portugal. The participants were aged $22-55$ years (mean 40.78). All had children (mean 2.22). They had lived in Canada for 6-30 years (mean 15.67). At the time of interviews, four were married, two were widowed, and four were divorced. All lived in the Portuguese community in Toronto, where they could keep their culture.

Data analysis involved the following steps established by the social phenomenological model ${ }^{(18)}$ : carefully reading interview transcripts; identifying and grouping units of meaning that developed into categories.

This study was guided by Alfred Schutz's social phenomenology, which can be used to clarify social aspects of life ${ }^{(19)}$. Specifically, the research focused on concepts including: the world of everyday life, natural attitude, 'we-relationship,' intersubjectivity, stock of knowledge, biographical situation, social action, and motivation (reason 'why' and reason 'to').

The first concept is the 'world of everyday life.' In this world, fundamental structures form by a pre-reflective state, occurring as people are influencing and being influenced. People act naturally in this state, and understanding human actions is necessary to be aware of the world of everyday life. The second concept is 'natural attitude,' which is affected by what an individual has experienced as a social reality ${ }^{(20)}$. A person consciously reflecting on her own actions will begin to attribute meaning to each individual action: these actions are natural attitudes. The third concept is the 'we-relationship,'when one attributes meaning to an action through face-to-face relationships. A person in a 'we-relationship' understands the experience of others, and others understand the experience of the person. This two-way process of sharing experiences occurs in a space and time, and the space, time, and process - all contain meaning, which is the fourth concept, 'intersubjectivity.'The fifth concept is 'stock of knowledge,' which is shaped by an individual's own interests, motives, desires, and ideological and religious commitments. The sixth concept is 'biographical situation,' the context of where and how an individual is raised. The seventh concept, 'social actions,' refers to how an individual's choice of action is related to other actions. The eighth concept is 'motives.'People choose their actions based on motives, i.e., 'reasons why' and 'reasons for' an action ${ }^{(21)}$. Reasons why are related to an individual's experiences, 'stock of knowledge,' and 'biographical situation.' Motives classified, as 'reasons for' are subjective, and guide future actions. To understand an individual's experience, researchers may focus on their 'reasons for,' or expectations about the future, in relation to the experienced situation, and anticipating or imagining their actions $^{(22)}$. We focused on all of these concepts throughout this research process.

\section{RESULTS}

The results were organized in two groups of categories: the first group (experiences of intimate partner violence, consequences of intimate partner violence, and responses to the violent situation) represents the 'reasons why' and the second group (needs and hopes for the future) represents the 'reasons for' according to Schutz.

Interviewees referred to experiencing IPV involving physical, verbal, and sexual abuse, humiliation, threats, and blaming. They also referred to the consequences of such abuse, including physical and mental health problems for themselves and effects on their children.

\section{EXPERIENCES OF INTIMATE PARTNER VIOLENCE}

Many women described experiencing physical abuse, which was extensive, and included hitting, kicking, and throwing objects:

He threw a construction work boot at me; do you know how big these are? He threw it in my chest, here. I fell on the floor and I could not breathe (E05); The father of my son assaulted me because I found out he was bisexual, so I took a session of angry punching, I ended up in the emergency room (E11).

Many other women referred to experiencing verbal abuse: He kept calling me names, and called me a bitch, and said that I had other men (E19); I cried! He verbally attacks me and I cry. I did not want to speak with him because if I speak to him, I know it would get worse and it will never stop. I go to my room, I cry (E12).

Some women referred to humiliation, and said that they thought this humiliation was meant to keep them down, for their partner to feel more powerful within their relationship: He no longer cares about offending me in front of those who are 
our friends. He called me names, which sometimes was worse than hitting. He became a person low, low in my eyes. He does not know how respect me (E19);

It is the humiliation! It's the thing I hate the most: humiliation. He had a good life. He knows that I had a really difficult life in Brazil. I was divorced. I had a daughter and that my situation was not like his situation. He always humiliated me! He said: Why do you want this or that, if you came from Brazil and brought nothing? That made me very sad... even until today he is humiliating me. There is a lot of humiliation. It's a lot (E18).

Sexual abuse was another form of IPV experienced by participants; it shares similarities with other types of violence, with the added component of unwanted sexual threats or interactions:

Several times he came home and tried to rape me. When you don't want to have sex with somebody else and the other person forces you, it is rape. It is rape. I was raped twice (E15);

He came to me and said: If you don't sleep with me tonight, I will do this or that (E05).

Threatening was identified as another type of abuse that the participants experienced; they referred to threats to their children's or to their own safety:

It made me very scared because I said I was not going to marry him if he drank and he told me that if I did not marry him, he would kill me (laughs). This gave me a lot of fear in my heart and in my head. I was really afraid he would kill me! He always said that, that he'd kill me, kill me... I said I did not want to marry a man who was drunk, but he did not understand, just said he was going to kill me... kill me! (E16);

He said he was going to kill me if I separated from him. I was afraid be would do this (E19).

Participants also referred to blaming as a form of IPV. They said that their partners were not happy with many aspects of their lives and blamed the women for this - many women said that they were blamed for everything: I did absolutely notbing, but he considered me as guilty! He did hell to my head! (E06);

He blames me for not developing our daughter. He thinks she could be a lot better if I were a different kind of mother. He already said that I am not a good mother. He said that the marriage might be better if I were a better mother, a different one! It seems that he will like me if I'm a good mother. I have to be a good mother in his head (E01).

Together, these findings show that participants experienced violence in the forms of physical abuse, verbal abuse, humiliation, sexual abuse, threats, and blaming. They had to live in and negotiate harsh and violent conditions, with various consequences, as discussed below.

\section{CONSEQUENCES OF INTIMATE PARTNER VIOLENCE}

Participants identified consequences of their experience of IPV: health problems, effects on their children, and changes in their overall attitudes. Health problems included both mental and physical health problems, such as depression, fear, malnourishment, digestive problems, and stress, among others. Some participants were hospitalized as a result:

I had depression, exhaustion of nerves. I had to stay in hospital for crazy people twice. The first time I was like a baby. My cousin had to help me (E16);

I started using various medications for depression and he did not support that because he did not believe it was depression. We fought a lot (E19).

Participants also felt that IPV had negative effects on their children. Although the violence was directed at the mothers, the children were also exposed to it: they observed it and sometimes were involved in it, and were afraid:

She saw my daughter always had swollen eyes, always sad. She did not play with her classmates. She slept in the chair. Until one day she called the child protection agency and they were at school to talk to my daughter, but the girl was sobbing and was too afraid to tell what was happening at home because she was afraid that someone would take her away from me. She sobbed, poor girl, so now she is paying for it with health problems. My daughter got a trauma; she had to go to a psychiatrist! (E05);

My middle son saw it. When my son saw him (my husband) throw me on the ground, my son picked up the phone and said that he was going to call the ambulance and the police. My husband was afraid of being arrested so he grabbed my son and threw him against the wall. He slammed back against the wall (E19).

Both reported situations happened years ago and were reported to the police at that time. Participants experienced extensive and long-lasting negative feelings as a consequence of the violence. These feelings included "not wanting to be alone", "feeling down", "exhausted”, "afraid”, "unhappy”, "like a prisoner", and "disgusted" with their partners. Together, these findings reveal that violence - physical abuse, verbal abuse, humiliation, sexual abuse, threats, and blaming - had consequences for participants including physical and mental health problems, and negative effects on their children.

\section{PARTICIPANTS' RESPONSES TO THE VIOLENT SITUATION}

Participants responded to the violent situation by either staying with or leaving their husbands. Factors that hindered participants from leaving the situation included taking care of their husband, religious beliefs, and being isolated. Factors that helped participants leave included calling the police and getting support.

Some participants believed that, regardless of what they were going through, they must take care of their husband:

He spent six months in jail. The time he spent there, I always prayed for him, because I do not want anyone to hurt him. Do you know? I prayed because he was the father of my daughter (E05);

I had to test my limits. I worked like crazy. My husband came home. I supplied the family with food and my husband with all that he needed. I helped my husband to pay the lawyer and all bills at home. My husband did not even have a penny (E11). 
Religion was very important to the participants, who attended church regularly and often referred to God during their interview. Some chose to stay with their husbands based on religious beliefs:

People ask why I do not do anything, but I do not... I trust in God! (E15);

So I put myself in the background to take care of him as a child and this was my biggest mistake! Even in the law of God because if you pay attention our father says, love your neighbour as you love yourself.' So that means that you have to love yourself first and then love your neighbour (E11).

Another factor discouraging participants from leaving the violent situation was being isolated, which made it impossible for these women to leave:

He wants me to stay indoors. Only indoors. In his mind I have to be there. He needs to see me cooking and tidying up. He loves to see me cleaning the house all day! (E18);

Especially where we live there is no community. I've lived in neighbourhoods that I felt better. I had more people to talk to. There I could go at the bakery, talking in Portuguese. However, we moved away. Now I do not go out, it is day to day indoors (E01).

Some factors helped participants leave the violent situation. For example, some participants said that calling the police helped them:

I once had to call the police. I could not make it anymore. He was arrested and was to answer why he said that and they banned him from getting close to me (E16);

I could not stay with him and I knew he was not going to change, so I called the police, I did the report and also took the restraint order (E12).

Another factor encouraging participants to leave the violent situation was getting support from family members, friends, colleagues, and community centres:

I said, 'I cannot stand it! I cannot stand it!' I started coming here (the community centre), and they helped me. I come to the sessions every week. I now have contact with other people, with other ladies who had also gone through domestic violence (E05);

I called my boss and said that I could not go because my husband had previously being violent against me. She told me to go somewhere and ask for help and I went (E19).

\section{Needs AND hopes for the fUtUre}

Participants expressed hopes for the future including rebuilding their life with or without their husband. Women who desire to stay in the relationship are divided in two groups, one which has no expectation on her husband's changing and the other with the expectation that he will change. Between women who desire to rebuild a life without their husbands, some intend to do it by leaving their husband (getting divorced); others plan to get revenge. Other hopes included being happy, learning English, and being financially stable.
All participants wanted to rebuild their life after experiencing IPV. Those who wanted to rebuild life with their husband appeared to have no expectation of change, as evidenced by the following excerpts:

I live like this: not sure if I want to live apart or if I want to live in his way... I'm living this life awkwardly! It's the only way (E16);

As I see it, there is no solution, I cannot do anything. I have no freedom to leave (E19).

Some participants also referred to thinking their husband would change. They said they gave their partners another chance in the hopes that he would change:

I did not want to tell that he beat me because I knew she would be angry (crying) and I still had hope that he would change (E12);

I told him that he could only return home if he changed the way he is! I'll give you one last chance! (E05).

Some participants referred to their hopes for rebuilding their life without their husband in the future. Some said they wanted to "escape", leave the house, or "get a divorce". Others, while thinking about rebuilding their lives without their husbands, referred to wanting revenge on their husbands for the violence they had experienced. One participant said:

I wanted revenge. Do you understand? (E05);

and another commented: I wanted bim to feel (...) to see, what he was doing (...) (E15).

Other hopes for rebuilding life without their husband included being happy, learning English, and being financially stable: I plan to remake my life. I intend to find a person who loves me and respects me, who loves and respects my son, too! That's it! (E06); For my life, I wish to stabilize financially, try to give a good education for my son. I want my son to have a chance because the father tried to cut his opportunities (E19);

Going to work or study and continue your life! Thinking about what he did will not solve your problem (E15).

\section{DISCUSSION}

Among this group of Portuguese-speaking women in Toronto, the experiences of violence (physical, sexual, or emotional) had negative effects on their overall health, quality of life, and their children. These findings are consistent with other studies ${ }^{(4,6-8)}$.

The lives of our participants reflect Schutz's concept of the 'world of everyday life' (acting without reflecting deeply on behaviour): they lived, raised families, worked, and socialized in a largely Portuguese cultural environment (Schutz's concept of 'biographical situation').

Schutz's theory of social actions - things done in order to achieve something or because of (in response to) something - is reflected in a work ${ }^{(23)}$, which revealed that a victim's ability to deal with IPV is influenced by the expectations of the culture to which she belongs. Like the Japanese women 
studied in three urban areas in Japan ${ }^{(24)}$, the Portuguese women in this study are part of a patriarchal society. In this kind of community, as women move toward more gender equality through employment (financial independence) and social affiliations, their relationship with their partner becomes more strained ${ }^{(25)}$. The same author also reported that personality plays a role in the ability to adapt, as stronger-willed women appear to be better at creating relationships outside the home ${ }^{(25)}$.

Schutz's concept of 'motives' is reflected by the actions that our participants took after experiencing IPV. Their responses to IPV varied greatly. Some were motivated (i.e. Schutz's reasons why) to endure the violence, in the hopes of attaining peace within the relationship: being quiet, staying away from the husband, agreeing and giving in to his demands. Others were motivated by wanting to improve or escape the situation (i.e. Schutz's 'reasons for'). Some threatened to leave the situation or to call the police, some sought support, but many chose to remain in the situation.

These reasons - family (immediate and extended), religious, financial, guilt, and fear of loneliness - may have particularly strong influence among our participants who, as immigrants or refugees, were somewhat isolated from the community in general. Social isolation is also cited for reasons such as embarrassment, shame, or fear of rejection $^{(25)}$. Regardless of their reaction, our participants did have expectations: either that things would remain the same and they would just live with it; or that their actions would cause the situation to improve. A study that has explored social network structures and supports for women in violent relationships ${ }^{(26)}$ found that the social networks of women in violent relationships are small and offer less support than those of comparison women.

Both adult and older adult women see outside intervention as appropriate to coping with violence. However, the older adult women's group says that their actions might be constrained by things such as believing that they should be a better wife, that they should pray for the abuse to stop, and that they should be patient. Among our participants, it was not clear whether those who did not seek support felt there was inadequate support (i.e., accessibility, socially and culturally-appropriate) from social services, the police, or their church, or whether they did not seek help that was actually available for other reasons. Researches ${ }^{(10,27)}$ suggest that immigrants might be less likely to seek help for IPV because of many post-migration factors: lack of social supports, socioeconomic status of women in their home country, or lack of financial resources (of the victim or her partner). The presence of children, the type of victimization, and cultural values also influence women to seek help ${ }^{(27)}$.

A scoping review conducted with data from 2000 to 2015 concluded that there is a low level of education for nursing/midwifery staff and students, so many nurses lack knowledge and skills in identifying, understanding, and providing appropriate care for women living with $\mathrm{IPV}^{(28)}$. A study ${ }^{(2)}$ also refers to preparedness, lack of comfort, and consistency among health care providers facing IPV.
Legislative tools to address IPV among immigrants may promote availability, accessibility and effectiveness of services. These factors plus the understanding of their legal options, were important elements in helping women move out of abusive relationships ${ }^{(29)}$.

Schutz's concept of 'social action' links an individual's choice of action to the actions of others: IPV victims might do nothing because they saw no positive support available to them; or they might do something if they felt that others' (police, doctor, social worker) actions would positively influence the outcome of their action. The reactions of friends and families to IPV, and their support (or lack of support) affect the health of victims, often negatively, by minimizing the severity of the abuse the woman has endured, keeping it a secret, blaming the woman, or siding with the abuser ${ }^{(30)}$.

Our findings provide evidence supporting more education on IPV for Portuguese immigrant women in Toronto, public awareness, life skills development (e.g., the ability to earn and effectively manage money, to improve independence), and culturally appropriate community support programs. These needs, supported by our results, show that the better way to face IPV is to empower the victims to act the way they judge best for then. Professionals and services have to be prepared to support the victims and their families, independent from their needs and hopes. We can also recommend education services and resources directed to IPV professionals, the need for an effective screening tool, and having mandatory IPV screening in the health services ${ }^{(2,28)}$. Emergency nurses may be able to identify and respond to victims of $\mathrm{IPV}^{(1)}$.

Finally, 'efforts to help women who have experienced IPV must go beyond caring for individual patients and aim to change the cultural, political and social contexts that produce and maintain IPV'(30).

The interviews were conducted in Portuguese and later translated into English; some specificities and cultural nuances may have been lost during this process.

\section{CONCLUSION}

Our results suggest that getting a divorce is not always an option for Portuguese immigrant women who experience IPV, so health professionals and social workers should provide care and support according to the women's needs. However, the choices and the actions of participants are influenced by their daily lives, including their beliefs and culture as well as post-migration factors such as language barriers. English classes, better job opportunities, and improved social support might be priorities in helping women rebuild their lives, with or without their partners. It also education on violence to health professionals, mainly to nurses and midwives, to better important to promote undergraduate and post-graduate degree prepare these professionals to identify cases of violence in the health services and/or in the community services; and to better conduct the cases. Including forensic nursing courses at the universities might help to improve this lack of knowledge and attitude. 


\section{RESUMO}

Objetivo: Este estudo foi realizado para compreender as experiências de violência contra o parceiro íntimo entre mulheres de países de língua portuguesa que vivem em Toronto. Método: Um estudo fenomenológico foi realizado com 10 mulheres que foram selecionadas por líderes do centro comunitário. As entrevistas foram transcritas, traduzidas e analisadas por categorias. Resultados: As consequências da violência incluíam problemas de saúde, impacto na vida das crianças e sentimentos negativos. Os fatores que impediam a mulher de se separar dos parceiros violentos foram crenças religiosas, tarefas diárias desafiadoras, e a necessidade de cuidar do marido, e os que as incentivavam a deixar o parceiro, a obtenção de apoio familiar e da polícia. Algumas mulheres expressaram esperança em relação ao futuro com o seu marido. Outras desejavam a separação ou a vingança. Seus planos para reconstruir suas vidas sem o marido incluíam ser feliz, aprender Inglês e ser financeiramente estável. Conclusão: A utilização desses resultados pode implicar a melhoria do cuidado para essas mulheres.

\section{DESCRITORES}

Violência Doméstica; Emigrantes e Imigrantes; Violência por Parceiro Íntimo; Maus-Tratos Conjugais; Enfermagem Forense.

\section{RESUMEN}

Objetivo: Este estudio se llevó a cabo para comprender las experiencias de violencia contra la pareja íntima entre mujeres de países de lengua portuguesa que viven en Toronto. Método: Un estudio fenomenológico fue realizado con 10 mujeres que fueron seleccionadas por líderes del centro comunitario. Las entrevistas fueron transcritas, traducidas y analizadas por categorías. Resultados: Las consecuencias de la violencia incluían problemas de salud, impacto en la vida de los niños y sentimientos negativos. Los factores que impedían a la mujer de separarse de las parejas violentas fueron creencias religiosas, tareas diarias desafiadoras y la necesidad de cuidar a sus maridos; y los que las incentivaban a dejar al compañero: la obtención de apoyo familiar y la policía. Algunas mujeres expresaron esperanza con respecto al futuro con su marido. Otras deseaban la separación o la venganza. Sus planes para reconstruir sus vidas sin el marido incluían ser feliz, aprender inglés y ser financieramente estable. Conclusión: La utilización de esos resultados puede implicar la mejoría del cuidado a esas mujeres.

\section{DESCRIPTORES}

Violencia Doméstica; Emigrantes e Inmigrantes; Violencia de Pareja; Maltrato Conyugal; Enfermería Forense.

\section{REFERENCES}

1. Ali P, McGarry J, Dhingra K. Identifying signs of intimate partner violence. Emerg Nurse. 2016;23(9):25-9. doi: 10.7748/en.23.9.25.s25.

2. Thomas SA, Oliver G, Bloom T, Gudehus S, Sherman J, Harris R. Intimate partner violence: enhancing vigilance of screening, treatment, and referral in the primary care setting. West J Nurs Res. 2016;38(10):1379-80.

3. Kelly UA, Gonzales-Guarda RM, Taylor J. Family violence and nursing practice. In: Humphreys J, Campbell JC, editors. Family violence and nursing practice. 2th ed. New York: Springer; 2010. p. 51-83.

4. Devries KM, Mak JYT, García-Moreno C, Petzold M, Child JC, Falder G, et al. Global health. The global prevalence of intimate partner violence against women. Science. 2013;340(6140):1527-8. doi:10.1126/science.1240937

5. Minayo MCS, Souza ER, Paula DR. Revisão sistemática da produção acadêmica brasileira sobre causas externas e violências contra a pessoa idosa. Ciênc Saúde Coletiva. 2010;15(6):2719-28.

6. Lukasik P, Karakula-Juchnowicz H, Morylowska-Topolska J, Flis M, Krukow P. Long-term somatic consequences of intimate partner violence in primary care female patients. Pol Merkur Lekarski. 2015;39(234):372-6.

7. Ishida K, Stupp P, Melian M, Serbanescu F, Goodwin M. Exploring the association between intimate partner violence and women's mental health: evidence from a population-based study in Paraguay. Soc Sci Med. 2010;71(9):1653-61.

8. Scott-Storey K. Cumulative abuse: do things add up? An evaluation of the conceptualization, operationalization, and methodological approaches in the study of the phenomenon of cumulative abuse. Trauma Violence Abuse. 2011;12(3):135-50. doi: $10.1177 / 1524838011404253$

9. Varcoe C, Hankivsky O, Ford-Gilboe M, Wuest J, Wilk P, Hammerton J, et al. Attributing selected costs to intimate partner violence in a sample of women who have left abusive partners: a social determinants of health approach. Can Public Policy. 2011;37(3):359-80.

10. Ahmad F, Rai N, Petrovic B, Erickson PE, Stewart DE. Resilience and resources among South Asian immigrant women as survivors of partner violence. J Immigr Minor Health. 2013;15(6):1057-64. doi:10.1007/s10903-013-9836-2.

11. Fong J. Chinese immigrant women confronting male violence in their lives. In: Fong J, editor. Out of shadows: woman abuse in ethnic, immigrant, and aboriginal communities. Toronto: Women's; 2010. p. 186-214.

12. Rosenberd L. Praying for divorce: the abuse of Jewish women through Jewish divorce law. In: Fong J, editor. Out of shadows: woman abuse in ethnic, immigrant, and aboriginal communities. Toronto:Women's; 2010. p. 215-41.

13. Souto RQ, Guruge S, Merighi MA, Jesus MC. Intimate partner violence among older Portuguese immigrant women in Canada. J Interpers Violence. 2016 Apr;24. pii: 0886260516646101. [Epub ahead of print]

14. Madden K, Scott T, Sholapur N, Bhandari M. Prevalence of intimate partner violence among South Asian women living in Southern Ontario. J Immigr Minor Health. 2016;18(4):913-20. doi: 10.1007/s10903-015-0333-7.

15. Ahmad F, Smylie J, Omand M, Cyriac A, O'Campo P. South Asian immigrant men and women and conceptions of partner violence. Immigr Minor Health. 2015 Oct 15. [Epub ahead of print]

16. Godoy-Ruiz P, Toner B, Mason R, Vidal C, McKenzie K. Intimate partner violence and depression among Latin American women in Toronto. J Immigr Minor Health. 2015;17(6):1771-80. doi: 10.1007/s10903-014-0145-1. 
17. Canada. Government of Canada. Statistics Canada. Census Profile [Internet]. Toronto; 2011 [cited 2016 Apr 13]. Available from: https:// www12.statcan.gc.ca/census-recensement/2011/dp-pd/prof/index.cfm?Lang=E

18. Jesus MCP, Capalbo C, Merighi MAB, Oliveira DM, Tocantins FR, Rodrigues BMRD. The social phenomenology of Alfred Schütz and its contribution for the nursing. Revista da Escola de Enfermagem da USP. 2013;47(3):736-41. Available at: http://www.ncbi.nlm.nih.gov/ pubmed/24601154.

19. Merighi MAB, Jesus MCP, Domingos SRF, Oliveira DM, Baptista PCP. Being a nursing teacher, woman and mother: showing the experience in the light of social phenomenology. Rev Latino Am Enfermagem. 2011;19(1):164-70.

20. Schütz A, Luckmann T. Las estructuras del mundo de la vida. Buenos Aires: Amorrortu; 2003.

21. Schütz A. El problema de la realidade social. Buenos Aires: Amorrortu; 2003.

22. Schütz A. Estudios sobre teoría social. Buenos Aires: Amorrortu; 2003.

23. Akinsulure-Smith A, Chu T, Keatly E, Rasmussen A. Intimate partner violence among West African immigrants. J Aggres Maltreat Trauma. 2013;22(1):109-29. doi:10.1080/10926771.2013.719592

24. Nagae M, Dancy BL. Japanese Women's perceptions of intimate partner violence (IPV). J Interpers Violence. 2010;25(4):753-66. doi:10.1177/0886260509334413

25. Paat Y. Risk and resilience of immigrant women in intimate partner violence. J Hum Behav Soc Environ. 2014;24(7):725-40. doi:10.108 $0 / 10911359.2013 .853018$

26. Katerndahl D, Burge S, Ferrer R, Becho J, Wood R. Differences in social network structure and support among women in violent relationships. J Interpers Violence. 2013;28(9):1948-64.

27. Alvarez C, Fedock G. Addressing intimate partner violence with Latina women: a call for research. Trauma Violence Abuse. 2016 Sep 20. pii: 1524838016669508. [Epub ahead of print]

28. Crombie N, Hooker L, Reisenhofer S. Nurse and midwifery education and intimate partner violence: a scoping review. J Clin Nurs. 2016 July 14. doi: 10.1111/jocn.13376. [Epub ahead of print]

29. Briones-Vozmediano E, La Parra D, Vives-Cases C. Barriers and facilitators to effective coverage of Intimate Partner Violence services for immigrant women in Spain. Health Expect. 2015;18(6):2994-3006. doi: 10.1111/hex.12283. Epub 2014 Oct 13.

30. Guruge S. Intimate partner violence: a global health perspective. Can J Nurs Res. 2012;44(4):36-54.

Financial support: Coordenação de Aperfeiçoamento de Pessoal de Nível Superior (CAPES). Process n. 18390-12-9. 